$\begin{array}{lcc}\text { Rosaline Jeanette } & \text { / } & 130318114 \\ \text { Felix Widyadhana } & / & 130318115 \\ \text { Andy Marvin } & / & 130318133 \\ \text { Daniel Febryan } & / & 130318137 \\ \text { Steven Irawan } & / & 130318139\end{array}$

\title{
Review Jurnal Perekonomian Indonesia
}

\section{Indonesia's Efforts to Achieve Globally Competitive Human Resources}

\section{Ahmad Zafrullah Tayibnapis, Lucia Endang Wuryaningsih, Radita Gora}

Masalah yang dibahas pada jurnal ini adalah terkait dengan sumber daya manusia di Indonesia pada era revolusi industri 4.0. Dalam rangka beradaptasi di era ini, Pemerintah Indonesia telah berkomitmen membangun industri manufaktur yang memiliki daya saing global. Dalam hal ini, pemanfaatan teknologi, informasi, dan komunikasi yang sedang berkembang pesat dalam rangkaian proses produksi hendak dilakukan untuk mencapai efisiensi dan peningkatan kualitas produk.

Oleh karena itu, satu hal yang perlu diperhatikan adalah kesiapan dunia bisnis dalam membangun dan mempersiapkan sumber daya manusia dengan daya saing global. Dalam hal ini sumber daya manusia yang dimaksud harus memiliki talenta dan standard kompetensi yang tinggi dalam bidangnya masing-masing serta memiliki karakter yang kuat yang mampu berkompetisi secara global, terlebih mengingat mulai tergantikannya tenaga manusia oleh teknologi dalam berbagai bidang (automatisasi).

Untuk menjawab permasalahan ini, penulis telah menuliskan hasil penelitiannya terhadap beberapa hal terkait masalah yang ada. Bermula dari Human Development Index (HDI), dimana HDI merupakan indikator yang diukur berdasarkan angka harapan hidup, pendidikan, dan pendapatan per kapita. Indonesia sendiri memiliki HDI yang cukup tinggi, yaitu sebesar 70.81, hanya saja HDI ini cenderung tidak merata, dimana daerah-daerah pelosok seperti Nusa Tenggara dan Papua tidak mencerminkan HDI yang cukup tinggi ini.

Seperti yang dikatakan pada jurnal ini bahwa, "The quality of human resources is also inseparable from the problem of poverty hitting in Indonesia until the present time..." (Tayibnapis, Wuryaningsih, \& Gora, 2018), maka HDI dapat berpengaruh terhadap tingkat kemiskinan. Kemiskinan sendiri telah menjadi 
masalah setiap negara, tidak hanya negara berkembang tetapi juga negara maju, dan bahkan merupakan core problem bagi Indonesia sendiri. Berbagai upaya kebijakan telah dilakukan pemerintah, tetapi pemerintah sering lupa bahwa HDI harus ditingkatkan terlebih dahulu, karena tanpa sumber daya manusia yang kompeten, akan sulit untuk memerangi kemiskinan di Indonesia.

HDI pun dipengaruhi oleh pendidikan. Pendidikan di Indonesia sendiri, masih kalah, bahkan jauh di bawah banyak negara lain. Hal ini dikarenakan pendidikan di Indonesia hanya terfokus pada teori dengan penerapan yang minim atau bahkan tanpa penerapan. Pendidikan di Indonesia juga cenderung tidak mendukung siswa untuk mengutarakan opininya karena kesalahan dinilai sebagai sesuatu yang buruk. Hal-hal ini menyebabkan rendahnya kemampuan dasar dan hampir tidak adanya pencapaian dari siswa-siswi di Indonesia.

Upaya untuk memperbaiki pendidikan cenderung tidak dilakukan oleh mereka yang bertugas sebagai tenaga pendidik. Perubahan dari kurikulum 2006 ke kurikulum 2013 juga tidak mengubah banyak hal dalam metode pengajaran di sekolah-sekolah. Perubahan-perubahan yang dilakukan juga lebih terarah pada meningkatkan nilai yang tertera pada ujian para siswa, sehingga hanya sedikit atau tidak ada perubahan terhadap mindset mereka.

Padahal, seperti yang telah diketahui, di era globalisasi ini, persaingan tidak hanya datang dari sesama penduduk Indonesia, tapi dari seluruh dunia. Apabila tidak berkembang, tenaga kerja Indonesia tidak akan bisa bersaing dengan tenaga kerja dari seluruh penjuru dunia, terlebih dengan munculnya artificial intelligent dan automatisasi.

Individu-individu pada era industri 4.0 harus diberi kesempatan untuk mengembangkan keunikan yang lebih bernilai dari sekedar uang, kekuatan, dan pangkat. Hal ini dapat memicu meningkatkan keefektifan karyawan saat bekerja dan meningkatkan loyalitas karyawan dalam bekerja, yang dikarenakan mereka merasa bahwa keunikannya merupakan suatu hal yang positif dan tidak dibatasi dalam pengembangannya serta tidak ada unsur paksaan di dalamnya. 
Menghadapi revolusi industri 4.0 ini, manusia juga harus memiliki nilai lebih yang tidak dapat digantikan oleh mesin. Oleh karena itu, perusahaan juga memiliki tanggung jawab untuk mengembangkan sumber daya manusianya dengan berinovasi. Inovasi sendiri tidak hanya berarti menemukan sebuah produk yang baru dan unik, tetapi pengembangan kerja sama strategis, saling bersinergi dan berkolaborasi dengan partner untuk membentuk koordinasi yang kuat juga merupakan bagian dari sebuah inovasi.

Salah satu contohnya adalah PT Pertamina yang menerapkan Performance Management System dimana semua staff dan karyawan memiliki kesempatan untuk menyampaikan pendapatnya melalui coaching programs, dialogue day, dan feedback sessions. Selain itu, para karyawan juga dapat menyampaikan apa yang mereka inginkan. Dengan begitu, koordinasi dan sinergi antara semua stakeholder perusahaan dapat terbentuk dengan kuat, yang berdampak pada tercipta sumber daya manusia yang unggul dan dapat menjadi salah satu modal PT Pertamina untuk menghadapi tantangan perkembangan era industri 4.0 terutama dalam persaingan sumber daya manusia.

Selain membentuk koordinasi yang kuat, perusahaan akan semakin menguntungkan jika memiliki pegawai yang bertalenta dan lingkungan kerja yang kondusif. Linkungan kerja kondusif yang dimaksud adalah penerimaan terhadap perbedaan pendapat yang ada dan dukungan terhadap sebuah inovasi baru yang dikembangkan. Dengan begitu, karyawan akan bekerja dengan komitmen yang tinggi serta mendapat kepuasan terhadap lingkungan kerja yang berdampak pada peningkatan performa perusahaan dalam hal ini karena peningkatan produktivitas karyawan.

Dibalik semua itu, para pemimpin perusahaan memiliki tantangan yang dapat dibilang cukup berat dikarenakan harus memberikan pengarahan terhadap setiap individu yang bersangkutan untuk mewujudkan visi dan misinya ditengah perubahan dinamika yang saat ini marak terjadi. Hal-hal seperti motivasi dan kerja tim merupakan teori-teori yang sering diungkapkan untuk menyelesaikan masalah tersebut, namun nyatanya dalam kegiatan praktiknya tidak mudah direalisasikan. 
Keterlibatan setiap individu merupakan kunci utama agar kedua hal tersebut dapat terlaksana dengan baik dalam praktiknya. Namun, perlu diketahui banyak faktor yang mempengaruhi keterlibatan setiap individu seperti lingkungan kerja, kebijakan perusahaan, kompensasi karyawan, perilaku atasan dan rekan kerja, serta bentuk-bentuk lain yang dapat memberi kejutan kepada karyawan, seperti selama pernikahan, kelahiran, sakit, dll.

Satu hal yang harus dilakukan untuk mendukung minat karyawan adalah dengan membentuk pusat pelatihan kejuruan di beberapa kota besar di Indonesia untuk mengantisipasi kemunculan produk artificial intelligence yang diperkirakan akan menggantikan banyak profesi dan pekerjaan.

Sebagai kesimpulan, Indonesia sangat membutuhkan sumber daya manusia yang unggul untuk menghadapi revolusi industri 4.0. Di era ini pun perang untuk masalah talenta akan menjadi agenda utama bagi pemimpin perusahaan dan mereka berusaha mewujudkan manajemen talenta sebagai bisnis utama yang meliputi pengubahan mindset karyawan terkait dengan manajemen asset perusahaan.

Bakat harus mampu berkolaborasi dalam menerapkan kompetensi untuk memperoleh hasil yang optimal dan berkelanjutan. Selain itu, perusahaan juga diharapkan untuk membangun kemampuan organisasi yang tercermin dalam manajemen strategi dan kinerja, mengingat tingkat kapabilitas organisasi dalam strategi manajemen dan eksekusi dengan kinerja perusahaan memiliki hubungan yang erat. 


\section{Daftar Pustaka}

Tayibnapis, A. Z., Wuryaningsih, L. E., \& Gora, R. (2018). Indonesia's Efforts to Achieve Globally Comptitive Human Resources. International Journal of Humanities and Social Science Invention, 7(08), 6.

Creswell, John W., 2010, Research Design, Pendekatan Kualitatif, Kuantitatif dan Mixed. Pustaka Pelajar. Yogyakarta.

Dessler, Gary, 2005, Human Resource Development. New Jersey. Prentice Hall. Tenth Edition.

Flippo, Edwin B. 1984. Personal Management, Organization, and Strategy. Mason. Thomson. Third Edition.

Intipesan. Media Pengembangan SDM \& Manajemen.Vol. 03. Juli - Agustus 2015. Jakarta.

PTPN Magz. Majalah Internal Triwulan.Vol. 016/ Th-V.April - Juni 2015.

Rachman, Eillen and Billy Latuputty. 2017. Empati, Kunci Merangkul Bawahan. Experd Character Building Assesement \& Training.Kompas. 30 September 2017. Jakarta.

Sirait, Justime T. 2007. Memahami Aspek - Aspek Pengelolaan Sumber Daya Manusia dalam Organisasi. Grasindo. Jakarta.

Werther, William B. and Keith Darvis. 1996. Human Resource and Personal Management. Me. Grow Hill. Fifth Edition. New York. 